\title{
PENGARUH KOMPETENSI SUMBER DAYA MANUSIA, PEMANFAATAN TEKNOLOGI INFORMASI DAN SISTEM PENGENDALIAN INTERNAL TERHADAP KUALITAS LAPORAN KEUANGAN LEMBAGA PERKREDITAN DESA (LPD) DI KECAMATAN KUTA SELATAN
}

\author{
Ni Putu Diah Utari, Luh Kade Datrini ${ }^{1}$ dan Ni Luh Putu Ratna Wahyu Lestari ${ }^{2}$ \\ Fakultas Ekonomi dan Bisnis Universitas Warmadewa Denpasar, Bali \\ Email : diahutaript98@gmail.com
}

\begin{abstract}
ABSTRAK
Penelitian ini bertujuan untuk mengetahui pengaruh kompetensi sumber daya manusia, pemanfaatan teknologi informasi dan system pengendalian internal terhadap kualitas laporan keuangan LPD di Kecamatan Kuta Selatan. Jumlah sampel yang digunakan sebanyak 46 responden. Metode pengumpulan data dilakukan dengan menggunakan kuesioner. Teknik analisis data yang digunakan yaitu uji validitas dan reliabilitas, analisis regresi linier berganda, uji asumsi klasik, koefisien determinasi, uji $\mathrm{F}$ dan uji t dengan bantuan program IBM SPSS Statistics version 20.0 For Windows. Hasil penelitian ini menunjukkan bahwa kompetensi sumber daya manusia, pemanfaatan teknologi informasi dan system pengendalian internal berpengaruh positif terhadap kualitas laporan keuangan LPD di Kecamatan Kuta Selatan.
\end{abstract}

\section{Kata Kunci: Kompetensi Sumber Daya Manusia, Pemanfaatan Teknologi Informasi, Sistem Pengendalian Internal, Kualitas Laporan Keuangan}

\section{PENDAHULUAN}

LPD sebagai lembaga keuangan dan lembaga kepercayaan dalam melaksanakan usahanya harus mengungkapkan informasi secara tepat waktu, memadai, jelas, akurat, dapat bandingkan dan dapat mudah diakses oleh masyarakat sesuai dengan haknya. Informasi yang berkualitas adalah informasi yang mudah dipahami, bebas dari hal yang menyesatkan dan kesalahan material. Selain itu, informasi berkualitas juga menyajikan secara jujur tentang apa yang seharusnya disajikan, relevan dan dapat diperbandingkan.

Persoalan tentang kualitas laporan keuangan saat ini sedang hangat diperbincangkan masyarakat, banyaknya kasus mengenai buruknya kualitas laporan keuangan di Indonesia masih menjadi isu hangat yang perlu diteliti lebih dalam. Hal ini merupakan bukti dari kurangnya kompetensi 
sumber daya manusia dan buruknya pemanfaatan teknologi informasi, serta kurangnya system pengendalian internal sehingga dapat memberikan pengaruh terhadap kualitas laporan keuangan. Rendahnya kualitas laporan keuangan, secara umum disebabkan oleh beberapa factor yaitu kompetensi sumber daya manusia, pemanfaatan teknologi informasi dan system pengendalian internal.

Untuk meningkatkan peran LPD, perlu dirintis program pelatihan sumber daya manusia, pendamping dan konsultasi usaha yang pada akhirnya akan meningkatkan peluang penyaluran dana yang berbasis pengembangan ekonomi wilayah. Peningkatan pemanfaatan teknologi informasi dalam operasional LPD juga akan mendorong peningkatan efisiensi serta memastikan peningkatan kualitas layanan operasional LPD. Kompetensi sumber daya manusia merupakan salah satu faktor penting dalam penyusunan laporan keuangan yang memiliki kualitas nilai informasi yang baik sehingga dapat digunakan oleh pengguna informasi keuangan. Melihat dari fenomena sebelumnya dapat diketahui bahwa sistem pengendalian internal belum berjalan dengan baik karena masih terdapat penyalahgunaan dana dan kecurangan lainnya. Dari kondisi ini harus menjadi bahan pertimbangan LPD untuk meningkatkan pengendalian internalnya. Kondisi ini juga akan dapat mempengaruhi kualitas laporan keuangan. Maka dari itu, peneliti ingin meneliti lebih lanjut mengenai "Pengaruh Kompetensi Sumber Daya Manusia, Pemanfaatan Teknologi Informasi dan Sistem Pengendalian Internal terhadap Kualitas Laporan Keuangan LPD di Kecamatan Kuta Selatan"

Berdasarkan uraian diatas maka yang dapat menjadi rumusan masalah dalam penelitian ini yaitu:

1. Apakah kompetensi sumber dayan manusia berpengaruh positif terhadap kualitas laporan keuangan LPD di Kecamatan Kuta Selatan?

2. Apakah pemanfaatan teknologi informasi berpengaruh positif terhadap kualitas laporan keuangan LPD di Kecamatan Kuta Selatan?

3. Apakah system pengendalian internal berpengaruh positif terhadap kualitas laporan keuangan LPD di Kecamatan Kuta Selatan?

\section{TINJAUAN PUSTAKA}

1. Teori Agensi 
Teori keagenan ditekankan untuk mengatasi dua permasalahan yang dapat terjadi dalam hubungan keagenan. Dalam laporan keuangan, perusahaan bertindak sebagai agen mempunyai kewajiban menyajikan informasi yang bermanfaat bagi para pengguna informasi keuangan.

\section{Teori Stewarship}

Teori ini didesain bagi para peneliti untuk menguji situasi dimana para eksekutif dalam perusahaan sebagai pelayan dapat termotivasi untuk bertindak dengan cara terbaik pada prinsipalnya. Sumber daya manusia akan lebih mengutamakan kepentingan organisas dengan caramemaksimalkan kompetensi dalam hal menyelesaikan tugas dan fungsinya demi tercapainya tujuan oganisasinya

3. Teori Technology Acceptance Model (TAM)

\section{Technology Acceptance}

Model (TAM) mengasumsikan bahwa penggunaan sistem pada kenyataannya ditentukan oleh niat perilaku pengguna yang didasarkan pada persepi kebermanfaatan dan kemudahan penggunaan. Hubungan antara persepsi kegunaan dan tujuan perilaku didasarkan pada ide bahwa dalam penyusunan suatu organisasi, orang-orang membentuk tujuantujuan terhadap perilaku yang diyakininya akan dapat meningkatkan kualitas laporan keuangan.

4. Kompetensi Sumber Daya Manusia

Dalam penyusunan laporan keuangan yang berkualitas sangatlah dibutuhkan Sumber Daya Manusia yang memiliki pemahaman mengenai akuntansi. Sumber daya manusia merupakan suatu acuan dalam membuat laporan keuangan yang berkualitas karena yang menyusun laporan keuangan adalah mereka yang sudah menguasai standar akuntansi.

5. Pemanfaatan Teknologi Informasi Pemanfaatan teknologi informasi adalah perilaku/sikap akuntan menggunakan teknologi informasi untuk menyelesaikan tugas dan meningkatkan kerja. Pemanfaatan teknologi informasi berarti memanfaatkan teknologi dalam pengolahan data untuk mempermudah kerja pegawai.

6. Sistem Pengendalian Internal 
Menurut Ikatan Akuntan Publik Indonesia (2011) bahwa: "sistem pengendalian internal merupakan suatu proses yang dijalankan oleh dewan komisaris, manajemen, dan personil lain yang didesain untuk memberikan keyakinan yang memadai tentang pencapaian kualitas laporan keuangan yang dilihat dari keandalan laporan keuangan, efektifitas dan efesiensi operasi serta kepatuhan terhadap hokum dan peraturan yang berlaku.

7. Kualitas Laporan Keuangan

Kualitas laporan keuangan merupakan suatu informasi yang dapat memudahkan pengguna dan pembaca untuk memahami dan dapat diasumsi kan dalam pengetahuan yang memadai tentang suatu aktifitas ekonomi, bisnis, akuntansi serta dapat mempelajari informasi dengan ketekunan yang wajar.

\section{METODE PENELITIAN}

1. Tempat Penelitian dan Obyek Penelitian

Tempat penelitian ini dilakukan pada LPD di Kecamatan Kuta Selatan yang berjumlah 9 LPD dan objek penelitian ini adalah kompetensi sumber daya manusia, pemanfaatan teknologi informasi dan system pengendalian internal terhadap kualitas laporan keuangan LPD di Kecamatan Kuta Selatan.

2. Populasi dan Sampel Penelitian

Populasi dan sampel dalam penelitian ini adalah 9 LPD dan 46 pegawai yang terdiri dari Pamucuk, Penyarikan, Patengan, Kabag Dana, Kabag Kredit dan Kabag Pembukuan) yang bekerja di LPD di Kecamatan Kuta Selatan.

3. Metode Pengumpulan Data Metode pengumpulan data yang digunakan adalah Observasi, Dokumentasi, Wawancara dan Kuesioner.

4. Instrumen Penelitian dan Pengujiannya

Peneliti menggunakan jenis instrumen kuesioner dengan pemberian skor sangat tidak setuju (SS) diberi bobot 5, setuju (S) diberi bobot 4, kurang setuju (KS) diberi bobot 3, tidak 
setuju (TS) diberi bobot (2)

dan sangat tidak setuju

(STS) diberi bobot 1 .

Kualitas instrumen

penelitian ditentukan

dengan uji validitas dan uji

reliabilitas,

5. Metode Analisis Data
Uji Asumsi Klasik (Uji Normalitas, Uji Heterokedastisitas, Uji Multikolonieritas, Analisis Regersi Linier Berganda, Koefisien Determinasi $\left(\mathrm{R}^{2}\right)$, Uji F dan Uji t.

\section{HASIL DAN PEMBAHASAN}

Hasil analisis regresi dengan program SPSS versi 20.0 for Windows dapat dilihat pada Tabel 1 berikut:

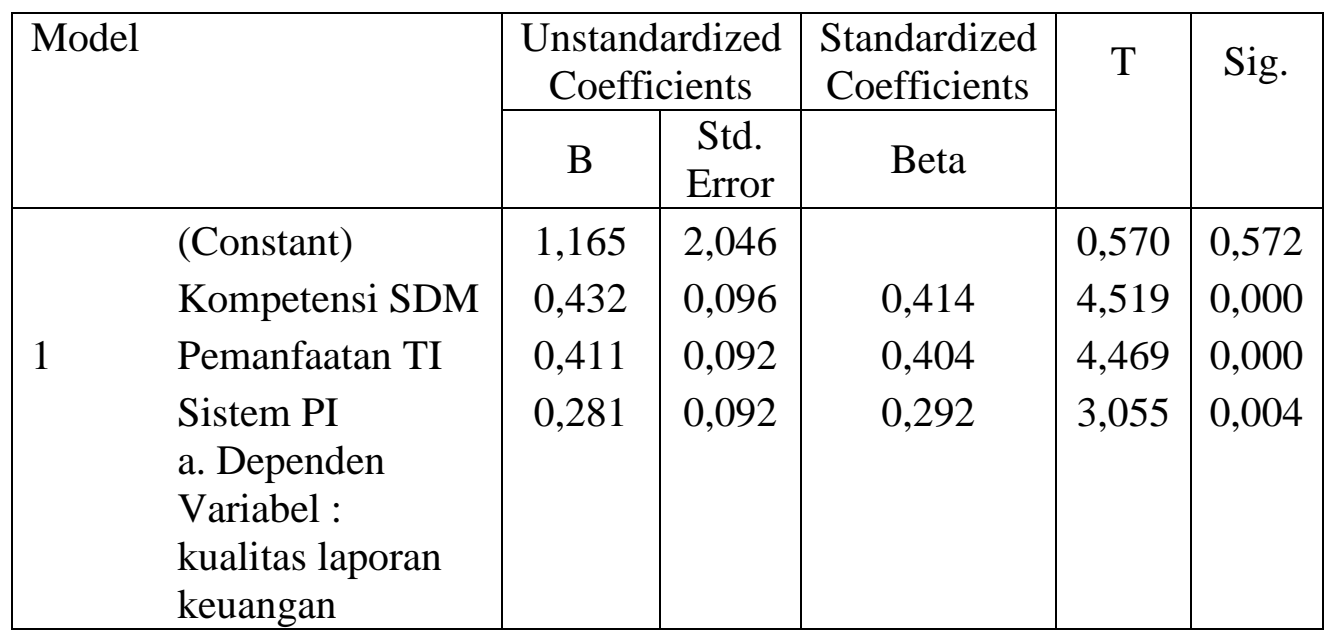

Berdasarkan data pada tabel 1 dapat diketahui bahwa hasil uji statistik $t$ yang diperoleh variabel Kompetensi Sumber Daya Manusia memiliki $\mathrm{t}$ hitung sebesar 4,519>t tabel 2,018 dan diperoleh koefisien regresi sebesar 0,414 dengan nilai signifikan 0,000, karena nilai signifikansi kompetensi sumber daya manusia $\left(X_{1}\right)$ 0,000 lebih kecil dari 0,05, ini menunjukkan komepetensi sumber daya manusia berpengaruh positif terhadap kualitas laporan keuangan. Maka hipotesis pertama yang menyatakan kompetensi sumber daya manusia berpengaruh positif terhadap kualiats laporan keuangan dapat diterima (H1 diterima). 
Berdasarkan data pada tabel 1 dapat diketahui bahwa hasil uji statistik $\mathrm{t}$ yang diperoleh variable Pemanfaatan Teknologi Informasi memiliki t hitung sebesar 4,469>t tabel 2,018 dan diperoleh koefisien regresi sebesar 0,404 dengan nilai signifikan 0,000 , karena nilai signifikan Pemanfaatan Teknologi Informasi (X2) 0,000 lebih kecil dari 0,05 ini menunjukkan pemanfaatan teknologi informasi berpengaruh positif terhadap kualitas laporan keuangan. Maka hipotesis kedua yang menyatakan pemanfaatan teknologi informasi berpengaruh positif terhadap kualiats laporan keuangan dapat diterima ( $\mathrm{H} 2$ diterima).

Berdasarkan data pada tabel 1dapat diketahui bahwa hasil uji statistik t yang diperoleh variable Sistem Pengendalian Internal memiliki t hitung sebesar 3,055 > t tabel 2,018 dan diperoleh koefisien regresi sebesar 0,292 dengan nilai signifikan 0,000 , karena nilai signifikansi Sistem Pengendalian Internal $\left(X_{3}\right)$ 0,000 lebih kecil dari 0,05 ini menunjukkan system pengendalian internal berpengaruh positif terhadap kualitas laporan keuangan. Maka hipotesis ketiga yang menyatakan system pengendalian internal berpengaruh positif terhadap kualiats laporan keuangan dapat diterima (H3 diterima)

Berdasarkan (Uji F) menunjukan nilai $\mathrm{F}$ sebesar 35,966 dengan nilai signifikan sebesar $0,000<0,05$, ini berarti model regresi yang digunakan sudah layak.

\section{PENUTUP}

1. Simpulan

a. Kompetensi sumber daya manusia berpengaruh positif terhadap kualitas laporan keuangan. Hal ini berarti bahwa semakin baik kompetensi sumber daya manusia yang dimiliki LPD di Kecamatan Kuta Selatan maka akan meningkatkan kualitas laporan keuangan pada LPD di Kecamatan Kuta Selatan.

b. Pemanfaatan teknologi informasi berpengaruh positif terhadap kualitas laporan keuangan. Hal ini berarti bahwa 


$\begin{array}{lr}\text { semakin } & \text { baik } \\ \text { pemanfaata } & \text { teknologi } \\ \text { informasi } & \text { yang } \\ \text { dilakukan } & \text { LPD }\end{array}$

Kecamatan Kuta Selatan

maka akan meningkatkan kualitas laporan keuangan pada LPD di Kecamatan Kuta Selatan

c. Sistem pengendalian internal berpengaruh positif terhadap kualitas laporan keuangan. Hal ini berarti bahwa semakin baik sistem pengendalian internal yang dilakukan LPD di Kecamatan Kuta Selatan maka akan meningkatkan kualitas laporan keuangan pada LPD di Kecamatan Kuta Selatan.

2. Saran

a. Bagi LPD di Kecamatan Kuta Selatan

Berdasarkan hasil LPD di Kecamatan Kuta Selatan diharapkan selalu meningkatkan kompetensi sumber daya manusia melalui pemberian pelatihan serta pendidikan, serta selalu menggunakan teknologi informasi yang ada dengan baik dan teknologi informasi yang digunakan agar nantinya bias membantu pegawai dalam meningkatkan kualitas laporan keuangan. LPD di Kecamatan Kuta Selatan juga hendaknya terus melakukan pengendalian internal dengan baik untuk meningkatkan kualitas laporan keuangan

b. Bagi Peneliti Selanjutnya.

Bagi peneliti selanjutnya hendaknya menambahkan variabel lainnya seperti locus of control, penerapan SAP, pendidikan dan pemahaman akuntansi selain itu dalam diperlukan penambahan jumlah sampel dan memperluas ruang lingkup penelitian yang tidak hanya terbatas di 
LPD di Kecamatan Kuta

Selatan.

\section{DAFTAR PUSTAKA}

Didik, Nurendah. 2015. Pengaruh Sistem Informasi Akuntansi, Sistem

Pengendalian Intern dan Kompetensi Sumber Daya Manusia terhadap Kualitas Laporan Keuangan Daerah dengan Faktor Eksternal sebagai Pemoderasi (Studi Kasus Pada Pemerintah Daerah Kabupaten Magelang). Diponegoro Journal of Accounting (Volume 4, Nomor 2).

Paramitha, Dharmadiaksa, 2019, Pengaruh Kompetensi Karyawan dan

Teknologi Informasi pada Kualitas Laporan Keuangan LPD dengan Pendidikan sebagai Pemoderasi. EJurnal Akuntansi Universitas Udayana (Vol. 26. 1).
Primantari, Dewi, 2016, Kualitas Laporan Keuangan Daerah Dilihat Dari

Pemanfaatan Teknologi Informasi dan Kompetensi Sumber Daya Manusia. Jurnal Ekonomi Warmadewa.

Romney,Marshall. 2017. Sistem Informasi Akuntansi. Jakarta: Salemba Empat.

Suwardjono. 2017. Teori Akuntansi: Perekayasaan Pelaporan Keuangan. Yogyakarta: BPFE

Sugiyono, 2015, Metode Penelitian Kuantitatif Kualitatif dan R\&D.

Penerbit Alfabeta Bandung

Yadiati, Winwin. 2016. Kualitas

Pelaporan Keuangan. Jakarta:

Kencana 